\title{
Pelatihan OSN Matematika Melalui Soal Berbasis Critical Thinking Skill Bagi Siswa SMP Negeri 4 Tanjungpinang
}

\author{
Mariyanti Elvi*1 ${ }^{*}$, Metta Liana², Dios Sarkity ${ }^{3}$, Dina Fitriyah ${ }^{4}$ \\ 1,2,3,4Fakultas Keguruan dan Ilmu Pendidikan, Universitas Maritim Raja Ali Haji \\ *e-mail: mariyantielvi@umrah.ac.id
}

\begin{abstract}
The National Science Olympiad (OSN) is one of the government's strategies to improve the quality of education in Indonesia. The purpose of OSN is to develop critical, systematic, creative, innovative and productive thinking skills. Critical thinking skills is a present skill that must be developed by students. The results of the OSN which is not optimal, one of which is caused by not optimal preparation by the school in dealing with OSN selection. The purpose of this activity is to equip students of SMP Negeri 4 Tanjungpinang so they are ready Mathematics Olimpiade selection by giving questions based on critical thinking skills. The results of this activity are (1) students are very competitive and enthusiastic in participating in training, (2) students are also motivated to participate in OSN 2020 selection, (3) the application of critical thinking skills makes it easier for students to analyze questions and solve them.
\end{abstract}

Keywords : OSN; critical thinking skills; mathematics

\section{Abstrak}

Olimpiade sains nasional (OSN) merupakan salah stu strategi pemerintah untuk meningkatkan kualitas pendidikan di Indonesia. Tujuan dari pelaksanaan OSN adalah untuk mengembangkan kemampuan berpikir kritis, sistematis, kreatif inovatif, serta produktif. Kemampuan berpikir kritis atau critical thinking skills merupakan keterampilan masa kini yang harus dikembangkan oleh siswa. Hasil OSN yang kurang maksimal, salah satunya disebabkan oleh kurang optimalnya persiapan yang dilakukan oleh pihak sekolah dalam menghadapi seleksi OSN. Tujuan dari kegiatan PkM ini adalah untuk membekali siswa SMP Negeri 4 Tanjungpinang sehingga siap menghadapi seleksi OSN Matematika dengan pemberian soal-soal berbasis critical thinking skills. Hasil dari kegiatan ini adalah (1) siswa sangat kompetitif dan antusias dalam mengikuti pelatihan, (2) siswa juga termotivasi untuk mengikuti seleksi OSN 2020, (3) penerapan critical thinking skills membuat siswa lebih mudah dalam menganalisis soal serta menyelesaikannya.

Kata kunci : OSN; critical thinking skills, matematika

\section{PENDAHULUAN}

Pendidikan merupakan salah satu alat ukur kemajuan suatu bangsa. Semakin baik kualitas pendidikannya, maka akan semakin maju bangsa tersebut. Kualitas pendidikan merupakan hal penting yang harus diperhatikan untuk mencapai tujuan pendidikan nasional. Hal ini berarti peningkatkan kualitas pendidikan merupakan salah satu point penting yang harus diutamakan. Kualitas pendidikan di Indonesia masih tergolong rendah. Berdasarkan world education rangking yang dilakukan oleh Organization for economic cooperation and development (OECD) pada tahun 2017, Indonesia berada pada rangking ke 57 dari total 65 negara. Hal ini dilihat dari segi membaca, matematika dan ilmu pengetahuan (Rusyanto, 2019). Berbagai strategi sudah dilakukan pemerintah, mulai dari meningkatkan kualitas guru hingga kualitas peserta didik.

Salah satu strategi pemerintah untuk meningkatkan kualitas pendidikan adalah mengadakan Olimpiade Sains Nasional (OSN). OSN merupakan program tahunan Kementerian Pendidikan dan Kebudayaan untuk meningkatkan mutu pendidikan terutama bidang sains. Pelaksanaan OSN dimulai dari seleksi tingkat sekolah, kabupaten/kota, propinsi dan nasional. Penyelenggaraan OSN sesuai satuan tingkat pendidikan, mulai dari tingkat Sekolah Dasar (SD), Sekolah Menengah Pertama (SMP) dan Sekolah Menengah Atas (SMA) (Kemendikbud, 2019). 
Tujuan dari pelaksanaan OSN ini diantaranya: (1) mengembangkan bakat dan minat siswa dibidang sains, (2) menumbuhkembangkan kemampuan berpikir kritis, sistematis, kreatif inovatif, serta produktif, (3) menanamkan sifat kompetitif bagi peserta didik (Kemendikbud, 2019). Berbagai bidang studi diperlombakan dalam penyelenggaraan OSN salah satunya matematika. Matematika merupakan matapelajaran yang dapat mengembangkan daya nalar, kreativitas dan kemampuan berpikir kritis. OSN matematika menampilkan soal-soal tidak rutin, dan sangat berbeda dengan soal yang dipelajari di sekolah. Penyelesaian soal-soal tersebut membutuhkan kemampuan kritis dan kreatif dalam menterjemahkan soal dan menyelesaikannya.

Sejak OSN diadakan pada tahun 2002, kegiatan ini telah menjadi motivati bagi sekolah dan peserta didik untuk berpartisipasi dan menampilkan kemampuan yang terbaik. Pemerintah Provinsi Kepulauan Riau telah menyelenggarakan OSN setiap tahunnya, dengan mengutus perwakilan siswa dari tingkat satuan pendidikan SMP ke OSN tingkat nasional. Khusus penyelenggaraan OSN tingkat SMP bidang matematika pada tahun 2019, menunjukkan perolehan medali utusan satuan pendidikan SMP dari Provinsi Kepulauan Riau belum maksimal. Rekapitukasinya dapat dilhat pada Tabel 1 berikut.

Tabel I. Daftar Peraih Medali OSN 2019 Jenjang SMP Bidang Matematika

\begin{tabular}{cccc}
\hline Provinsi & Emas & Perak & Perunggu \\
\hline Banten & 2 & - & 1 \\
\hline Jawa Barat & 1 & 2 & 1 \\
\hline Jawa Timur & 1 & 1 & 2 \\
\hline DKI Jakarta & - & 2 & 3 \\
\hline Jawa Tengah & - & 2 & - \\
\hline Riau & 1 & - & 1 \\
\hline Kepulauan Riau & - & 1 & - \\
\hline Lampung & - & 1 & - \\
\hline Sulawesi Utara & - & 1 & 1 \\
\hline Kalimantan Barat & - & - & 1 \\
\hline Sulawesi Selatan & - & - & 1 \\
\hline Bali & - & - & 15 \\
\hline DI. Yogyakarta & - & - & \\
\hline Jumlah & 5 & 10 & \\
\hline
\end{tabular}

Sumber : Rekapitulasi Peraih Medali OSN 2019

Dari rekapitulasi perolehan medali OSN tingkat SMP pada bidang matematika, perolehan medali didominasi oleh provinsi yang ada di pulau Jawa. Sementara itu, Provinsi Kepulauan Riau memperoleh satu medali perak dan satu medali perunggu. Belum maksimalnya hasil diatas, perlu adanya dorongan dari pihak sekolah untuk meningkatkan mutu peserta didik sehingga dapat bersaing di tingkat nasional, khususnya untuk sekolah-sekolah yang berada di daerah Tanjungpinang.

Berdasarkan hasil wawancara dengan pihak sekolah, sekolah sudah memberikan pembekalan OSN kepada siswa melalui guru pendamping. Namun, pembekalan tersebut belum optimal, yang disebabkan oleh beberapa hal diantaranya (1) frekuensi pelatihan yang masih kurang. Adakalanya pelatihan diadakan ketika akan seleksi tingkat kab/kota saja. (2) guru pendamping tidak mengetahui dengan baik materi yang muncul dalam soal-soal OSN, dan (3) kurangnya nalar dan kemampuan berpikir kritis (critical thinking skill) siswa dalam menterjemahan soal-soal. Padahal critical thinking skill merupakan kemampuan abad 21 yang dibutuhkan oleh siswa (Kharbach, 2012). Critical thinking skill merupakan salah bagian dari high order thingking skill (HOTS) yang harus diorientasikan pada pembelajaran masa kini.

Ennis (2013) menyatakan bahwa berpikir kritis adalah cara berpikir reflektif yang masuk akal dan berdasarkan logika yang berfokus pada menentukan apa yang harus dipercaya dan 
dilakukan. Berpikir kritis menanamkan pemikiran yang tepat dan sistematis sehingga mendatangkan kreatifitas dalam menyelesaikan permasalahan (Lau, 2011). Sejalan dengan itu Ismaimuza (2011) mengatakan berpikir kritis merupakan berpikir analitis untuk mengklarifikasi, membandingkan serta menarik kesimpulan.

Lau (2011) menerangkan bahwa berpikir kritis harus mampu untuk : (1) memahami hubungan antar ide, (2) merumuskan ide dengan ringkas dan tepat, (3) mengidentifikasi dan membangun argument, (4) menganalisis masalah dengan sistematis, serta (5) mengevaluasi kesalahan. Kemampuan -kemampuan ini sangat dibutuhkan siswa untuk menyelesaikan soal-soal non rutin yang muncul dalam OSN. Selain itu menanamkan keterampilan berpikir kritis diharapkan siswa mampu mengembangkan pola pikir agar dapat bersaing ditingkat global (Novtiar, 2017). Oleh karena itu, pada kegiatan PkM ini lebih difokuskan kepada keterampilan tingkat tinggi yaitu critical thingking skill dalam menyelesaikan soal-soal OSN matematika. Hal ini sejalan dengan tujuan OSN dalam menumbuhkembangkan kemampuan berpikir kritis siswa sehingga siap bersaing dalam kompetisi nasional maupun internasional.

\section{METODE}

Pengabdian kepada masyarakat $(\mathrm{PkM})$ ini dilakukan dengan metode pelatihan kepada siswa SMP untuk mendapatkan pembekalan dan pemahaman dalam menghadapi OSN matematika atau kompetisi matematika Nasional. Pelatihan ini lebih menekankan pada kemampuan berpikir kritis siswa dalam menyelesaikan soal-soal dengan standar OSN.

Kegiatan ini dibagi dalam beberapa tahap: (1) pra kegiatan, (2) kegitan pelatihan, serta (3) evaluasi. Pada tahap tahap pra kegiatan tim PkM melakukan survey ke beberapa sekolah yang ada di Tanjungpinang. Kami melakukan wawancara dengan pihak sekolah terkait kendala yanh dihadapi sekolah dalam melakukan pelatihan OSN. Selain itu kami juga menawarkan pembekalan OSN berupa pelatihan bagi siswa yang mempunyai potensi untuk mengikuti OSN dalam waktu 5 minggu. Pada tahap kedua, dilakukan kegiatan pelatihan pra OSN bagi siswa selama 5 minggu, dan pada tahap evaluasi kami melakukan tes tertulis dan angket.

PkM dilakukan di SMP Negeri 4 Tanjungpinang dengan jumlah siswa yang mengikuti pelatihan sebnyak 10 orang. Siswa ini merupakan siswa yang mempunyai potensi untuk mengikuti OSN Matematika yang terdiri dari kelas VII dan VIII. Tim PkM ini terdiri dari 4 orang dosen dan 5 orang mahasiswa yang sedang melakukan kegiatan PLP di sekolah tersebut. Analisis metode yang digunakan adalah motede deskriptif untuk melihat pemahaman dan kemamppuan berpikirir kritis siswa dalam menyelesaikan soal-soal OSN serta ketertarikan siswa dalam mengikuti pelatihan pra OSN ini.

\section{HASIL DAN PEMBAHASAN}

Pengabdian kepada masyarakat (PkM) ini, dilakukan selama 5 minggu setiap hari sabtu pada pukul 13.00-15.00 WIB. Kegiatan PkM terdiri dari pembukaan, pelatihan dan evaluasi. Pembukaan PkM dilakukan pada minggu pertama yang dihadiri oleh wakil Kepala SMP Negeri 4 Tanjungpinang. Pada kegiatan ini juga disampaikan sedikit paparan terkait OSN Matematika, seperti pokok materi, silabus, metode pelatihan yang akan dilakukan, serta target yang akan dicapai dalam pelatihan ini. Pembukaan diakhiri dengan penyerahan modul pembelajaran oleh Tim PkM kepada pihak sekolah, serta pengambilan foto bersama. Kegiatan pembukan pra-OSN ini dapat dilihat pada Gambar 1. 


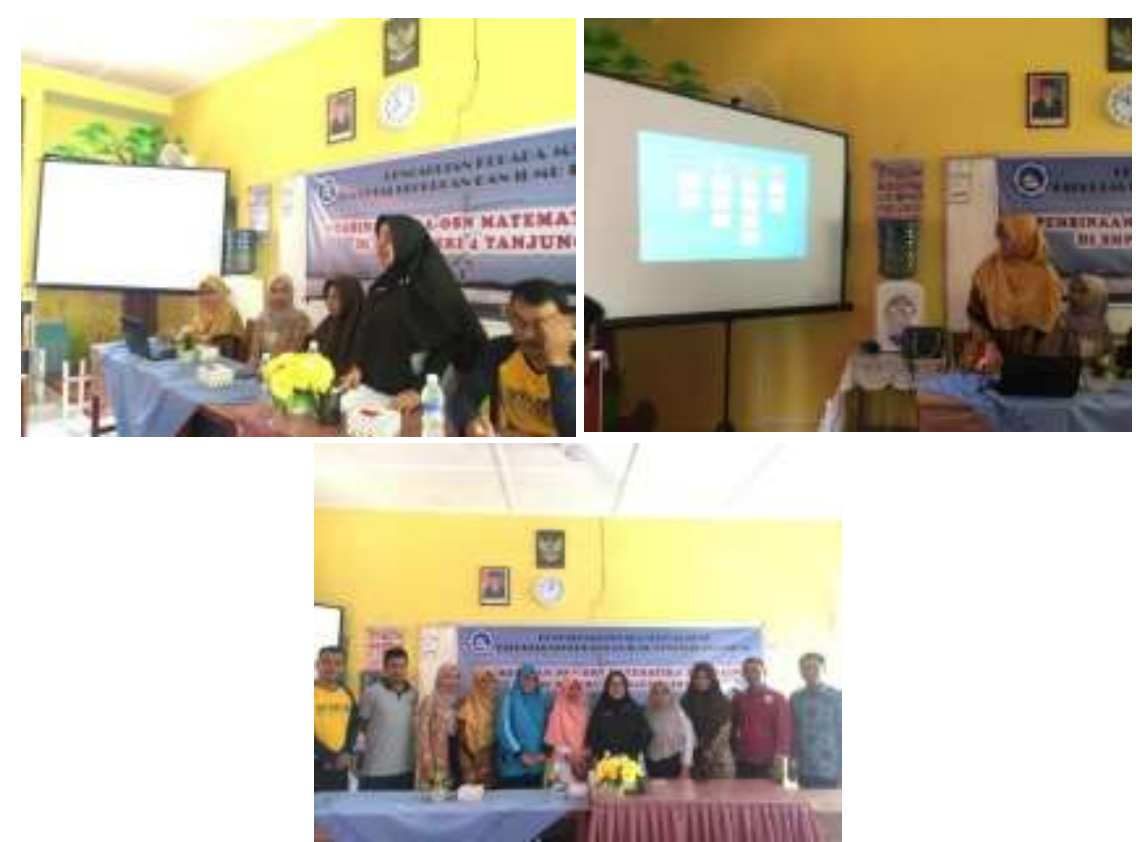

Gambar 1. Pembukaan Pelaksanaan Pelatihan Pra OSN

Kegiatan pelatihan pra OSN dilakukan pada minggu ke-2 sampai dengan minggu ke-5. Materi pelatihan yang diberikan yaitu aljabar dan statistika. Materi aljabar diberikan pada minggu ke 2 dan ke 3, sedangkan materi staristika pada minggu ke 4 dan ke 5. Pelatihan diawali dengan perkenalan dan motivasi siswa untuk belajar. Ice breaking juga dilakukan untuk membuat suasana kelas menjadi baik. Kemudian dilanjutkan dengan pemaparan tentang materi OSN beserta soalsoal berbasis critical thinking.

Langkah-langkah pembelajaran critical thinking yang dimodifikasi dari Abdullah (2013) yaitu (1) memunculkan ide/konsep, (2) menghubungkan antar ide/konsep, (3) merumuskan konsep, (4) melakukan analisis, serta (5) mengevaluasi jawaban. Siswa diajak berinteraksi dan berdiskusi untuk memunculkan ide-ide dalam penyelesaikan soal. Selain itu, berdiskusi dengan siswa akan membuat suasana belajar menjadi kondusif (Syukron, 2014). Beberapa contoh soal berbasis critical thinking yang digunakan pada pelatihan dapat dilihat pada Gambar 2 berikut,

Pada saat makan siang, Taufan
menghabiskan $1 / 3$ dari uang yang ia
miliki. Setelah makan siang, ia
menerima uang dari temannya sebesar
Rp. 25. 000,00. Sore harinya, ia
membeli tiket bioskop sebesar Rp.
$40.000,00$ dan membeli makanan
seharga Rp. 12.500,00. sekarang
uangnya tersisa Rp. $52.500,0$, berapa
uang taufan sebelum makan siang?

Diberikan empat bilangan yang
berbeda $a, b, c$ dan $d$. Jika rata - rata
$a$ dan $b$ adalah 50, rata - rata $b$ dan
$c$ adalah 75 , serta rata - rata $c$ dan
$d$ dalah 70, maka rata - rata $a$ dan
$d$ adalah....

Gambar 2. Contoh soal berbasis critical thinking

Kegiatan terakhir adalah evaluasi berupa tes tertulis dan penyebaran angket. Tes tertulis dilakukan untuk melihat perkembangan critical thinking siswa selama pelatihan dan hasil dari tes tertulis ini, digunakan oleh sekolah sebagai acuan dalam memilih siswa untuk mewakili sekolah 
dalam tahap seleksi OSN tingkat kota/kabupaten. Sedangkan penyebaran angket dilakukan untuk melihat respon siswa terhadap pelatihan pra OSN yang lakukan oleh Tim PkM. Hasil sebaran angket dapat dilihat pada Tabel 2.

Tabel 2. Respon siswa setelah mengikuti pelatihan Pra OSN

\begin{tabular}{|c|c|c|}
\hline No & Aspek/ deskripsi & Presentase \\
\hline & Pemahaman konsep & \\
\hline 1 & $\begin{array}{l}\text { Memahami lebih baik konsep pada materi OSN setelah } \\
\text { mengikuti pelatihan pra-OSN }\end{array}$ & $95 \%$ \\
\hline 2 & $\begin{array}{l}\text { Terampil memahami masalah/soal melalui pelatihan pra- } \\
\text { OSN }\end{array}$ & $88 \%$ \\
\hline \multirow[t]{2}{*}{3} & $\begin{array}{l}\text { Memahami langkah-langkah penyelesaian soal setelah } \\
\text { mengikuti pelatihan pra-OSN }\end{array}$ & $85 \%$ \\
\hline & $\begin{array}{l}\text { Rata-rata respon pemahaman materi } \\
\text { Motivasi belajar }\end{array}$ & $89,3 \%$ \\
\hline 1 & $\begin{array}{l}\text { Motivasi untuk belajar mandiri dalam mempersiapkan diri } \\
\text { mengikuti OSN setelah mengikuti pelatihan pra-OSN }\end{array}$ & $90 \%$ \\
\hline 2 & $\begin{array}{l}\text { Tertarik dan bersemangat mengikuti kegiatan OSN setelah } \\
\text { mengikuti pelatihan pra-OSN }\end{array}$ & $92 \%$ \\
\hline \multirow[t]{2}{*}{3} & $\begin{array}{l}\text { Kesiapan untuk mengkompetisi dalam OSN setelah } \\
\text { mengikuti pelatihan pra-OSN }\end{array}$ & $85 \%$ \\
\hline & $\begin{array}{l}\text { Rata-rata respon motivasi belajar } \\
\text { Pengajar/pemateri }\end{array}$ & $89 \%$ \\
\hline 1 & Mampu memberikan pemahaman konsep dengan baik & $90 \%$ \\
\hline 2 & $\begin{array}{l}\text { Mampu menberikan bimbingan dengan baik dalam } \\
\text { penyelesaian soal }\end{array}$ & $93 \%$ \\
\hline \multirow[t]{2}{*}{3} & $\begin{array}{l}\text { Mampu memberikan motivasi, saran, serta strategi dalam } \\
\text { mengikuti OSN }\end{array}$ & $90 \%$ \\
\hline & $\begin{array}{l}\text { Rata-rata respon pengajar } \\
\text { Alokasi waktu }\end{array}$ & $91 \%$ \\
\hline 1 & $\begin{array}{l}\text { Alokasi waktu yang diberikan sangat efektif berdasarkan } \\
\text { pembagian materi setiap pertemuan }\end{array}$ & $80 \%$ \\
\hline
\end{tabular}

Berdasarkan tabel diatas,persentase respon siswa dalam memahami materi adalah 89,3\%. Artinya pelatihan pra OSN dengan menggunakan soal-soal berbasis critical thinking skill membuat siswa dapat memahami materi dengan baik, selain itu siswa dapat meningkatkan keterampilan dalam menyelesaikan soal-soal standar OSN. Hal ini sejalan dengan Ismaimuza (2011) bahwa critical thinking/berpikir kritis membuat siswa mudah menganalisis permasalahan yang diberikan sehingga memudahkan siswa dalam menyelesaikan soal.

Pada indikator motivasi siswa dalam mengikuti pelatihan ini tergolong baik dengan persentase $89 \%$. Siswa sangat antusias mengikuti pelatihan, karena hasil dari pelatihan ini akan menjadi acuan sekolah dalam menentukan siswa yang akan mengikuti OSN. Selain itu respon siswa terhadap pengajar yaitu 91\%. Hal ini menunjukkan bahwa pengajar dapat menyajikan materi dan memberikan bimbingan dalam penyelesaikan soal dengan baik. Sedangkan persentase untuk indikator alokasi waktu tergolong cukup yaitu $80 \%$. Waktu pelatihan yang singkat, membuat pengajar tidak dapat menyampaikan semua materi pokok pada silabus OSN. Berdasarkan hasil evaluasi tes dan angket, menyatakan bahwa kegiatan pelatihan Pra OSN ini terlaksana dengan baik dan dapat memberikan kontribusi bagi siswa dan sekolah dalam mengikuti seleksi OSN. 


\section{KESIMPULAN}

Kegiatan PkM dengan tema pelatihan persiapan OSN di SMP Negeri 4 Tanjungpinang berjalan dengan baik. Adapun kelebihan dalam kegiatan PkM ini sebagai berikut: (1) siswa sangat kompetitif dan antusias dalam mengikuti pelatihan, (2) siswa juga termotivasi untuk mengikuti seleksi OSN 2020, (3) penerapan critical thinking skills membuat siswa lebih mudah dalam menganalisis soal serta menyelesaikannya. Sedangkan kekurangannya antara lain alokasi waktu yang singkat sehingga semua materi pokok tidak dapat tersampaikan dan keterbatasan dana kegiatan membuat siswa yang ikut pelatihan hanya 10 orang.

\section{UCAPAN TERIMA KASIH}

Tim PkM mengucapkan terimakasih kepada kepala SMP Negeri 4 Tanjungpinang, yang telah memfasilitasi kami dalam pengadakan kegiatan pelatihan pra OSN ini. Selanjutnya Tim PkM juga mengucapkan terimaaksih kepada LP3M UMRAH yang telah mengizinkan kami untuk melakukan kegiatan PkM ini, serta terimakasih tak lupa kami sampaikan kepada mahasiswa PLP Universitas Maritim Raja Ali Haji yang telah membantu dalam keterlaksanaan kegiatan ini.

\section{DAFTAR PUSTAKA}

Abdullah, I. H. (2013). Berpikir Kritis Matematik. Jurnal Matematika dan Pendidikan Matematika, 2(1), 66-75

Ennis, R.H. (2013). The Nature of Critical Thinking: Outlines of General Critical Thinking Dispositions and Abilities (Online), Retrieved May 19, 2020, from http://www.criticalthinking. net/longdefinition.html.

Ismaimuza, D. (2011). Kemampuan Berpikir Kritis Matematika Ditinjau dari Pengetahuan Awal Siswa. Jurnal Pendidikan Matematika, 2(1), 11-20

Kharbach, M. (2012). The 21st Century skills Teachers and Student Need to Have. Halifax: Creative Commons Attribution Mount Saint Vincent University.

Kemendikbud. (2019). Petunjuk Pelaksanaan Olimpiade Sains Nasional SMP tahun 2019. Dirjen Pendidikan Dasar dan Menengah. Retrieved April 28, 2020, from http://ditpsmp.kemdikbud.go.id/petunjuk-pelaksanaan-dan-silabus-osn-smp-tahun2019/

Kemendikbud. (2019). Rekapitulasi Peraihan Medali Olimpiade Sains Nasional Tahun 2019. Sekretariat Direktorat Jenderal Pendidikan Dasar dan Menengah. Retrieved April 28, 2020, from http://ditpsmp.kemdikbud.go.id/rekapitulasi-peraihan-medali-osn-tahun-2019/

Lau, J.Y.F. (2011). An Introduction to Critical Thinking and Creativity. Massachuset: John Wiley \& Sons Inc

Novtiar, C \& Aripin, U. (2017). Meningkatkan Kemampuan Brpikir Kritis Matematis dan Kepercayaan Diru Siswa SMP Melalui Pendekataan Open Ended. Jurnal PRISMA, 4(2), 119 131.

Rusyanto. (2019). Indonesia Masih Menghadapi Masalah dalam Pendidikan. Retrieved May 19, 2020, from https://siedoo.com/berita-22005-indonesia-masih-menghadapi-masalahdalam-pendidikan/

Syukron, B. (2014). Deep Dialogue / Critical Thinking (Konsep Solusi Pembelajaran Inovatif). Jurnal TAPIS, 14(2), 291-309 